Научная статья

УДК 821.512 .31

DOI 10.18101/2686-7095-2021-2-38-44

\title{
МОТИВ ВЗРОСЛЕНИЯ В ПОВЕСТИ «УБИТЬ ВРЕМЯ» Г. БАШКУЕВА
}

\author{
(C) Хандарова Ольга Владимировна \\ кандидат филологических наук, младший научный сотрудник, \\ Институт монголоведения, буддологии и тибетологии СО РАН (ИМБТ СО РАН) \\ Россия, 670047, г. Улан-Удэ, ул. Сахьяновой, 6 \\ olga.khandarova@gmail.com
}

\begin{abstract}
Аннотация. В статье на примере повести «Убить время» рассматриваются в сопоставлении сюжеты и образы миров детства и взрослой жизни в прозе Геннадия Башкуева. На основе анализа персонажной системы, композиционной структуры выявляется значимость мотива взросления. Показано, как сентиментальный характер изображения мира детства и мотив взросления помогают обнаружить конфликт в повести. Установлено, что мотив взросления является ключевым для понимания образа взрослого инфантильного героя.
\end{abstract}

Ключевые слова: Г. Башкуев, тема детства, повесть, персонаж, рассказчик, мотив взросления

\section{Для цитирования}

Хандарова О. В. Мотив взросления в повести «Убить время» Г. Башкуева // Вестник Бурятского государственного университета. Филология. 2021. Вып. 2. С. 38-44.

Тема детства является очень важной в творчестве русскоязычного бурятского писателя Геннадия Тарасовича Башкуева (род. 1954). Повесть для детей о дворовом улан-удэнском детстве «Прощай, мой Боливар!» (1991) позднее переработана в «Маленькую войну» (2013). Некоторые герои и сам рассказчик «Маленькой войны» узнаваемы в цикле новелл «Записки пожилого мальчика» (2007), также позднее переработанном в повесть «Убить время» (2016). Общим для всех перечисленных произведений является обращение к миру детства рассказчика схожи время, место, реалии, типажи персонажей, частично автобиографический образ главного героя. В настоящей статье на примере последней повести рассмотрим, какую роль в творчестве писателя играет мотив взросления.

В повести «Убить время» воспоминания главного героя начинаются с новеллы, посвященной двум эпизодам: из детства — случай чудесного спасения на реке, из взрослой жизни - смерть пациента из соседней палаты в кардиологическом отделении. Таким образом, в начале повести намечается структура, основанная на параллелизации событий детства и взрослой жизни, а также задается один из ключевых лейтмотивов - «жизнь есть любовь». Тонущий мальчик взмаливается: «Боженька, миленький мой, спаси, я еще не любил» [3, с. 211], и все кардиологическое отделение следит за романом пациента: «...верилось, отступит загрудинная боль и наступит весна. И тебя, немолодого, болезного, полюбит работница общепита» [3, с. 212]. По содержанию новеллы выходит, что мальчику дан шанс пожить (испытать любовь), а взрослому этот шанс незачем и так уже «укатали сивку горки страсти». По наблюдению исследователя, новелла в том числе задает идею «спасительного случая в судьбе мальчика и отсут- 
ствие спасения (везения) в жизни взрослого» [2, с. 62]. В целом мысль о взрослении как о разрушении наивности, восторженности, способности любить и наращивании циничного панциря, под которым жизнь перестает быть таким уж дорогим подарком, становится одной из сквозных идей повести.

Эта идея, на наш взгляд, проявляется и на уровне построения персонажной системы повести. Так, эпизодические персонажи повести, упоминаемые сразу в нескольких новеллах, служат не только для скрепления композиции. Все колоритные персонажи с характеристиками и историей, с отдельным жизнеописанием - только из воспоминаний детства: необъятная тетя Зина, задавившая любовника и судимая за это, сосед Емельянов, сожители Хохряковы, персональный пенсионер Корнеич, старик Агван и др. Эпизодические персонажи из воспоминаний взрослой жизни практически не удостаиваются характеристики: Олег, Сэнди, хозяин дачи и др. С одной стороны, колоритные персонажи создают контекст, «населяют» детские годы рассказчика, с другой стороны, эта разница словно служит наглядной иллюстрацией изменения мироощущения главного героя: заметен контраст между тем, с каким интересом воспринимает жизнь рассказчик-ребенок и с каким отстраненным равнодушием - взрослый рассказчик.

В повести противопоставлены семья родителей рассказчика в детстве и его собственная семья во взрослой жизни. В первом случае сознание рассказчика отводит значительное, первоочередное место любви в отношениях родителей между собой и к ребенку. Объективные бытовые трудности, проблемы отца с алкоголем и развод, выведенные на страницах повести, отходят на второй план и заслоняются образом счастливой семьи, наполненной любовью: «...однажды субботним вечером отец вернулся домой шибко навеселе и подарил маме капроновые чулки, а наутро, опохмелившись, объявил, что мы всей семьей идем в баню ... мама, сияя глазами, сказала, что он сошел с ума. Был солнечный морозный день, снег хрустел под валенками, искрясь, больно резал глаза. Отец шел по правую руку и нес чемодан, мама, смеясь, по левую, и когда попадалась ледовая дорожка, мы втроем дружно разбегались, и я, держась за руки взрослых и крича от счастья, катился по льду» [3, с. 256]. Момент расставания с отцом совпадает для мальчика со временем взросления, а после завершения этого процесса и начинается скучная жизнь, для описания которой больше подходит выражение «убить время».

Собственная семья рассказчика — жена и сын, изображена отстраненно. О сыне упоминается лишь в нескольких эпизодах: мы знаем, что он в детстве ходил на парад с красными флажками (которые потом пригодились на дуэли Толика), несколько раз носил дедов реглан, вырос, поступал, поступил, женился, уехал на заработки за границу. К жене рассказчик испытывает прежде всего чувство жалости: «она сильно уставала, жить с непутевым мужем, знаете ли...» $[3$, c. 282]; отношения с тещей представляют собой открытую вражду. Семейного счастья в жизни рассказчика не было (либо оно разрушено и о нем не вспоминается), работа для него тоже не имеет значения - в представленной на суд характеристике сказано коротко: «отлынивал от поручений и норовил уйти в отпуск вне очереди» $[3$, с. 240]. Поиски героем себя сублимируются в «адюльтеры, ссоры и обиды, выпивки и посиделки, свидания и прощания» [1, с. 39].

Образ счастливой семьи в повести остается недостижимой мечтой детства: «Со стороны это выглядит, наверное, смешно, давно нет мамы, давным-давно 
ушел отец, зато мне порой снится удивительный сон: над рекой встает туман, течение ленивое и мощное, но мне не страшно, потому что по правое весло сидит во всем чистом отец, по левое - мама в новых платье и капроновых чулках, они молча улыбаются мне, седому мальчику, сидящему у руля» [3, с. 257].

Разницу миров рассказчика-ребенка и рассказчика-взрослого иллюстрирует изображение дома в повести. Дом детства намечен штрихами и довольно красноречиво заслоняется образами двора, бараков, кочегарки, улицы Ленина, двора дома инвалидов и т. д. Однако сам образ счастливого семейного дома все же существует, хоть и сжимается до нескольких вещей, которые при этом вызывают весьма противоречивые чувства (определяемые чувством любви к отцу и его уходом из семьи) - это кожаная куртка-реглан отца и его же фибровый чемодан. Частью образа дома является также хлопочущая мать на кухне в подготовке к празднованию Нового года и само празднование - с оливье и селедкой под шубой, со «Старкой» и «Мадерой», «Крем-содой» и мандаринами, телевизором «Рекорд» и соседями.

Дом же взрослого рассказчика - неуютное место, в нем некуда приткнуться, можно только слоняться по нему, «нюхая свои подмышки». Жилища других персонажей повести так же бесприютны и бесприкаянны, часто содержат свидетельства о попойках: на кухнях Аллы, Оли-Пятницы, Толи Ссальника вытертые клеенки, линолеум, бегают тараканы, отстают обои, накурено и столы заставлены бутылками, Серега-Первый живет в подвале. Некое подобие жалостного и печального уюта встречает герой в квартире старой девочки Нади: «обои в мелкий цветочек, светильник из фальшивого хрусталя, подушка слабо и нежно пахнет духами» [3, с. 273]. Один из маркеров дома, уюта в повести - образ собаки: в деревне у дедушки был Шарик, в квартире старой девочки Нади - жалкая и преданная Дайна.

Максимально близкое к уютному дому пространство - дача приятеля, на которой рассказчик несколько летних недель проводит с Аленкой и ее сыном. Именно в эти моменты он кратковременно ощущает подобие семейного счастья: «по утрам, пока Алёнка спала, успевал сбегать к реке, искупаться, сделать зарядку, наносить воды в огромный ржавый бак и приготовить завтрак из яичницы и свежих огурцов» [3, с. 335].

Применительно к обстановке квартиры рассказчика: «зеркало, фибровый чемодан, старые газеты, поношенные детские вещи, обеденный стол, табуреты», исследователь говорит об образе «обжитого архаизированного пространства, средоточия культуры, духовности и покоя», которому противопоставляет образ «антидома» - камеры СИЗО [5, с. 101]. Действительно, в повести Башкуева вместо цельного образа уютного дома фигурируют «обжитые пространства» таково фрагментированное изображение родительского дома и описание собственной квартиры во взрослой жизни.

На наш взгляд, в ряду всех этих «пространств» камера тюрьмы, наоборот, не очень выделяется: она является лишь одной из локаций родного рассказчику пространства города в повести, знакомого, привычного и обжитого, что подтверждается тем, как быстро осваивается в ней рассказчик. В каком-то смысле, конечно, пространство города в повести является «комфортной средой существования человека и его семьи» [5, с. 101], однако это не исключает наличия в нем страшных мест, неприятных запахов и прочего пугающего и отталкивающего. 
По Башкуеву детство - это пора невинности, счастливым ребенком можно быть почти в любых условиях. Мир детства полон приключений, и пусть в деревне «лошадь оказалась старой, речка - ручьем, а собака - кривоногой дворняжкой», зато они были настоящими, от дедушки «пахло дымом дальних костров и странствий» и в гости к нему приходил таинственный сосед старик Агван [3, с. 241]. Романтическая мечта - важный мотив повести: в дальние странствия по Миссисипи всерьез мечтают пуститься дедушка и мальчик, лелеет мечту об освобождении всех угнетенных жителей Америки «Союз трех пистолетов», романтикой с пиратским привкусом отдает приключение по добыче корсета для девочки, комична, но и романтична дуэль уже взрослого Толика из-за измены подруги. В новеллах и эпизодах, описывающих романтические устремления героев, за непременной иронической окраской можно разглядеть вполне нежное отношение автора к героям, обуреваемым подобными чувствами и страстями. И даже городская дурочка, ждущая принца, заслуживает защиты именно за свою романтическую мечту.

Однако воспоминания о детстве, переживания детских приключений все время дополняются горькими, горестными ощущениями, часто перемежаемыми чувствами вины, стыда или обиды. Так, первое сильное увлечение девочкой, которое доводит мальчика буквально до лихорадочного состояния, быстро сменяется «зажимболом», подвиг по добыче корсета, который совершает он для нее, оборачивается подметанием в аптеке осколков бутыли вперемешку с собственной рвотой и постановкой на учет в детской комнате милиции. А романтическая и героическая миссия «Союза трех пистолетов» по освобождению угнетенного населения капиталистической Америки заканчивается тем, что мертвецки пьяный кочегар дядя Володя запускает портянкой в одного из участников союза, отчего тот теряет сознание. В каждой из подобных ситуаций подчеркивается, как ребенок сталкивается с жестокой и подчеркнуто некрасивой и мелкой правдой реального мира.

В описании же взрослой жизни рассказчика часто присутствуют перечислительные ряды: «...было душное лето, на даче сгорели огурцы, наши позорно проиграли в четвертьфинале, сын поступал в университет <..> Заказчики не расплачивались за поставленный товар, в стране был бардак, зарплату задерживали, сигареты продавали поштучно» [3, с. 277]. С одной стороны, эта отстраненность действительно свидетельствует об «оторопи» главного героя перед стремительно изменившимся временем [1, с. 37], с другой стороны, в ней можно обнаружить и свидетельство инфантильности, отказа героя от взросления.

Характеризуя возраст и степень зрелости главного героя, исследователь отмечает: «С одной стороны, ему уже сорок, опыт жизни достаточен, но негативен, беспорядочен. С другой стороны, ему всего сорок, он еще мальчик, глубоко “увязший” в своем детстве» [1, с. 35]. Вне повседневной рутинной жизни пожилого мальчика продолжают находить приключения, что характерно, в компании с такими же неповзрослевшими друзьями детства. Герои словно обращены в прошлое, где они все еще полны витальной энергии, где кипят настоящие страсти. Во взрослой жизни никого из дворовых друзей жизнь не пощадила: БорькаБоливар уже умер от сердечного приступа, предатель Серега-Первый, не умевший в детстве смотреть на звезды, промышляет тем, что поднимает упавшие мо- 
неты в проходе торговых рядов на рынке и живет в беспробудном пьянстве, ушастый Серега-Слон одиноко и грустно умирает, когда от него уходит жена.

Толик всю жизнь пытается бороться со своей детской кличкой - Ссальник. Этот травматизирующий фактор влияет на его взрослое поведение, и однажды на посиделках «по случаю удо» за измену подруги, ее поцелуй с собутыльником, Толик вызывает последнего на дуэль. Одного взрослого мужчину другой взрослый мужчина призывает в секунданты с помощью записки, подписанной тремя крестами - знаком «высшей степени секретности», означающим приказ, который «надо выполнить любой ценой» [3, с. 322].

Единственным товарищем детства, который остается на плаву и с какой-то определенностью закрепляется в жизни, становится приземленный и практичный хулиган Ренат. Поначалу он живет жизнью разбойника и ходит в тюрьму как на работу, получив свой первый срок после убийства отчима в шестнадцать лет и после этого отсидев много других сроков. Но впоследствии, несмотря на то, что именно Ренат становится причиной деградации семьи Аллы и ее дочерей, он сам же пытается все исправить - кодирует от алкоголизма Аллу, не устает воспитывать, наказывая и прощая, ее непутевую старшую дочь и гордится умницей и красавицей младшей.

В очередной раз удивляясь памятливости Рената на события детства, рассказчик подмечает: «Ренат застыл, что муха в янтаре, в том далеком времени, и, как знать, возможно, эта память не давала ему превратиться в законченного бандита» [3, с. 294]. Друзья детства рассказчика - это такие же, как он, пожилые мальчики, не наигравшиеся в игры, наивно-романтические и словно не наученные жить. Их детские воспоминания словно спасательный круг, но его действие ограничивается спасением души: земная жизнь пожилых мальчиков заканчивается быстро и грустно.

Говоря о мире детства в творчестве Башкуева, исследователь замечает, что рассказчик «заново, с восторгом переживает лучшую часть своей жизни <... картины собственного детства со своей богатой живописью - это своеобразное признание художника в любви к родному городу, который взрастил его, закалил характер, столкнул с подлинными жизненными ценностями - верностью, способностью к состраданию, подготовил к настоящей, суровой мужской жизни» $[4$, c. 98]. Уточним, что выделение мотива взросления как ключевого в сочетании с анализом сюжетных линий, системы персонажей, пространственных образов вскрывает серьезный конфликт в идиллическом, на первый взгляд, мире детства.

Одевая по утрам сына Аленки Коленьку, рассказчик удивляется тому, как, казалось, недавно сам был тем мальчиком, которого по утрам собирали в сад, и развернувшаяся нить воспоминаний о горестях детства (ненавистные бумазейные серовато-поносного цвета чулки, проливающаяся чернильницанепроливайка) заканчивается горьким вопросом: «Зачем существовало, трепетало все то, что накрыла огромная клякса жизни, поглотив, сожрав время?» [3, с. 236]. Гуманистический пафос творчества Г. Башкуева заключается в том, что за внешне отстраненным, ироничным образом рассказчика кроется «личное авторское чувство сожаления от того, что частная жизнь отдельного человека оказывается под давлением всего социального, огосударствленного, в окружении мира неуютного, неудобного для нормального человеческого существования» $[6$, c. 6]. 
За обычной, на первый взгляд, сентиментальностью рассказчика в воспоминаниях о детстве скрывается острая рефлексия по поводу эпохи, эксплицированная в мотиве взросления. «...зачем целое поколение мальчиков и девочек пролило мегалитры слез, осваивая никому не нужную в этом жестоком мире каллиграфию и прочие телячьи премудрости, зачем умерли постаревшие мальчики и девочки, так ни разу не применив на практике полученные на уроках правописания знания...» [3, с. 336] - одна из основных интенций повести звучит как вопрос: как получилось, что не объяснили самого главного - как быть взрослым? Ответ автора, закодированный в противопоставлении образов и сюжетов детства и взрослой жизни: потому что не научили любить. Значимость мотива взросления в творчестве Г. Башкуева интерпретируется нами как проявление глобальности проблемы осмысления поколенческого экзистенциального кризиса в постсоветской литературе.

\section{Литература}

1. Башкеева В. В. Между социализмом и капитализмом: драма героя в повести Г. Башкуева «Записки пожилого мальчика» // Вестник Бурятского государственного университета. 2018. № 2-3. С. 35-40. Текст: непосредственный.

2. Башкеева В. В. Драма брошенности в повести Г. Башкуева «Записки пожилого мальчика» («Убить время») // Вестник Бурятского государственного университета. 2018. № 2-4. С. 62-67. Текст: непосредственный.

3. Башкуев Г. Т. Убить время: повести разных лет. Улан-Удэ: Республиканская типография, 2019. 520 с. Текст: непосредственный.

4. Бороноева Т. А. Особенности автобиографизма в современной бурятской художественной культуре // Северо-Восточный гуманитарный вестник. 2015. № 4(13). С. 96-100. Текст: непосредственный.

5. Грязнова О. Б. Реализация концепта 'Дом/Родина' в прозе Г. Башкуева // Функционально-когнитивный анализ языковых единиц и его аппликативный потенциал: маериалы I Международной научной конференции. Барнаул: Изд-во Алт. гос. пед. академии, 2012. С. 100-102. Текст: непосредственный.

6. Имихелова С. С. О роли дебюта в творческой судьбе писателя (из опыта создания литературных биографий бурятских писателей) // Вестник Бурятского государственного университета. 2018. № 2-1. С. 3-11. Текст: непосредственный.

Статья поступила в редакцию 24.04.2021; одобрена после рецензирования 30.05.2021; принята к публикации 30.06.2021.

\section{MOTIVE OF GROWING UP IN «KILLING TIME» STORY BY GENNADY BASHKUEV}

\section{Olga V. Khandarova}

Cand. Sci. (Phil.), Senior Researcher

Institute for Mongolian, Buddhist and Tibetan Studies, SB RAS

6 Sakhyanovoy St., Ulan-Ude 670047, Russia

olga.khandarova@gmail.com

Abstract. The article compares the plots and images of the worlds of childhood and adult life in the prose by Gennady Bashkuev on the material of his "Killing Time" story. Based on the analysis of the character system and compositional structure, the significance of the growing up motive is revealed. The article shows how the sentimental character of depicting the 
world of childhood and the motive of growing up help to reveal conflict in the story. The motive of growing up is the key to understanding the image of an adult infantile hero.

Keywords: Gennady Bashkuev, childhood theme, story, character, narrator, motive of growing up

For citation

Khandarova $O$. V. Motive of growing up in "Killing Time" story by Gennady Bashkuev. Bulletin of Buryat State University. Philology. 2021; 1: 38-44 (In Russ.).

The article was submitted 24.14.2021; approved after reviewing 30.05.2021; accepted for publication 30.06.2021. 